\title{
THE PERFORMANCE OF GRASSLANDS KOPU WHITE CLOVER ON TWO DAIRY FARMS
}

S. C. Moloney, R. J. M. Hay and J. A. Lancashire Grasslands Division, DSIR, Palmerston North

\begin{abstract}
The performance of Kopu white clover was compared with that of Huia and Pitau under intensive dairy grazing management at Taupo and the Manawatu. Sampling included both dry matter production and detailed white clover stolon and leaf measurements.

These trials have shown that there are significant advantages to be gained from the use of Kopu over both Huia and Pitau. in rotationally grazed cattle wards, particularly during autumn and winter. At the Taupo site where Kopu was sown with high endophyte perennial ryegrass, seasonal white clover yields from Kopu were $120 \%$ greater than from Huja in autumn and $160 \%$ in winter. At the Manawatu site with Matua prairie grass as the grass component, the advantage of Kopu over Pitau was $105 \%$ in autumn, increasing to $150 \%$ by winter.

These results are discussed in relation to the significance of Kopu to dairy farming in the central and southern North Island region.
\end{abstract}

Keywords: rotationally grazed wards. cool season activity, erect habit, dairy pasture. intensive dairying

\section{INTRODUCTION}

Grasslands Kopu white clover, previously known as G18, has very large leaves, long petioles, thick fleshy stolons. an open erect growth habit and stem nematode resistance, suggesting a potential for use in intensive dairying in the North island (van den Bosch et a/. 1986).

This paper reports the performance of Kopu in mixed grass/clover swards under intensive dairy grazing management at two sites.

\section{SITES, METHODS AND MEASUREMENTS}

Site 1 (Taupo) is at Tirohanga $40 \mathrm{~km} \mathrm{NW}$ of Taupo at $430 \mathrm{~m}$ asl, on medium to high fertility Taupo sandy silt soil, $(\mathbf{p H}=\mathbf{5 . 9}$, Olsen $\mathbf{P}=\mathbf{2 2}, \mathrm{S}=16)$. The farm is on a 50 ha seasonal factory supply dairy unit, with milkfat production of $500 \mathrm{~kg} / \mathrm{ha}$. The climate is extremely variable, with hot summers, cool dry autumns and prolonged cold winters with a high incidence of frost. Rainfall is $1250 \mathrm{~mm}$ pa.

Site 2 (Manawatu) is $16 \mathrm{~km}$ south of Palmerston North at Linton, and is a good example of an intensive, high fertility, seasonal factory supply dairy unit. Soils are fine silty loams $(\mathrm{pH}=5.8-6.4$, Olsen $\mathrm{P}=13-35)$, and range from the more developed Rangitikei series to the very recent Manawatu series on which the trial is located. Milkfat production is $540 \mathrm{~kg} / \mathrm{ha}$ with total farm area $40 \mathrm{ha}$. Rainfall is $850-900 \mathrm{~mm}$, with summer and autumn being critical for feed supply.

At the Taupo site in the autumn of 1983, two mixtures ( 0.8 ha each) were established in a 1.6 ha paddock, both based on high endophyte perennial ryegrass sown at $20 \mathrm{~kg} / \mathrm{ha}$, and either Huia or Kopu sown at $3 \mathrm{~kg} / \mathrm{ha}$. DM production measurements began in June 1984, although estimation of annual DM production is possible only from January 1986. Four $(0.5$ $\mathrm{m}^{2}$ ) pasture frames were sited at representative areas within each mixture, and cut to a height of $2 \mathrm{~cm}$ at each sampling.

Detailed measurement of the white clover populations commenced in January 1987. From each of three transects, $3050 \mathrm{~mm}$ diameter cores were taken for detailed measurement of growing point (GP) density, stolon dry weight (SDW), stolon length (SL), leaf dry weight (LDW) and leaf area index (LAl), the ratio of leaf area to ground area occupied. 
At the Manawatu site, a 3.6 ha paddock was sown in the autumn of 1986 with two mixtures (1.6 ha each): Matua at $40 \mathrm{~kg} / \mathrm{ha}$ and either Pitau or Kopu at $3 \mathrm{~kg} / \mathrm{ha}$. After establishment the paddock was subdivided where the mixtures met, to give effective grazing control. Sampling methods were the same as used at the Taupo site and commenced in December 1986.

The trial paddock mixtures at both sites were placed into the normal paddock rotation, thus receiving intensive rotational grazing management under commercial conditions, from establishment.

\section{RESULTS}

\section{Taupo site}

Dry Matter. Although total DM yields were similar for both mixtures (eg in 1986 Kopu/ryegrass $17.9 \mathrm{t}$, cf Huia/ryegrass $17.7 \mathrm{t} \mathrm{DM/ha} \mathrm{pa),} \mathrm{differences} \mathrm{occurred} \mathrm{between} \mathrm{the}$ two clovers in their relative contribution to the totals. Kopu yields were greater than those of Huia (Figure 1). Further, at the autumn sampling of May 1987, ryegrass yield was higher with Kopu than with Huia $(P<0.05$, Figure 2), leading to greater accumulated means for the January-August period for ryegrass of $7100 \mathrm{~kg}$ DM/ha with Kopu compared with $5300 \mathrm{~kg}$ DM/ha with Huia.

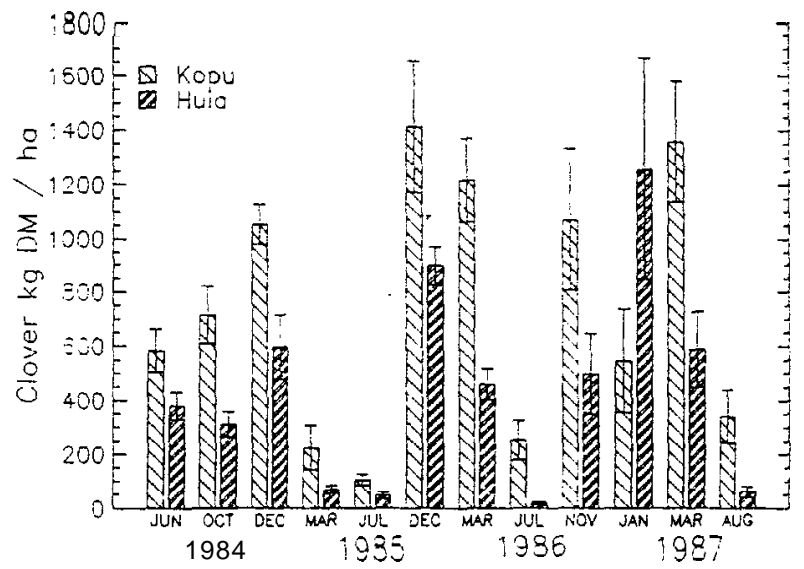

Figure 1: White clover yields (kg DMha) from comparative samplings between 1984 and 1987 at Site 1 (error bars denote SEMI.

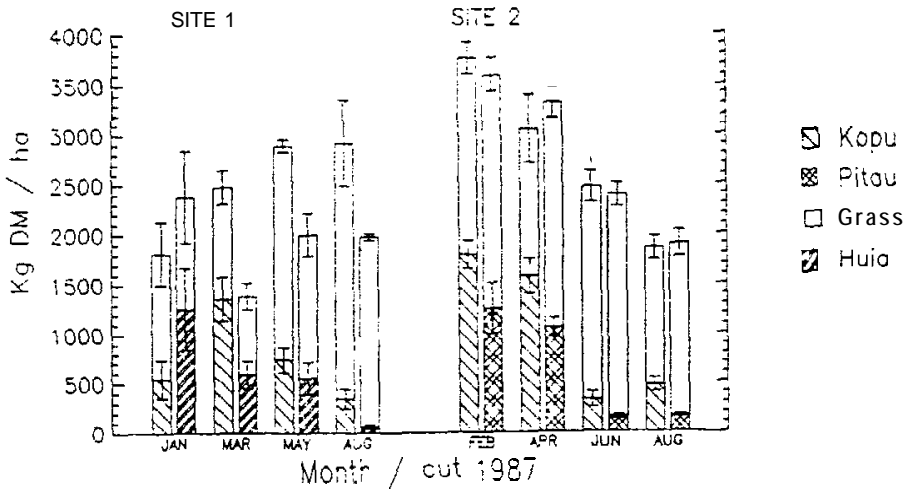

Figure 2: Sown grass and white cloveryields (kgDM/ha), from the the 1987 samplings at site 1 and site 2 (error bars denote SEM). 
On a seasonal basis, for the samplings between 1984 and 1987, the white clover DM advantage to Kopu over Huia in the autumn was $120 \%$ increasing to $160 \%$ in winter, and was significant $(P<0.05)$ in all four winters sampled (Figure 1). The advantage of Kopu over Huia was reduced in spring and summer.

Stolon and Leaf Measurements. Table 1 shows both cultivars doubling the number of growing points between the dry 1987 summer and the moist autumn. In autumn, Kopu showed a clear superiority to Huia in stolon mass and by winter this difference still favoured Kopu.

\section{Manawatu site}

Dry matter. At this site, total accumulated DM yields from December 1986 to August 1987 were the same for both mixtures, at 12.1 t DM/ha. Nor was there a difference in the grass component (Matua) between mixtures, however the white clover DM yield of Kopu was greater than that of Pitau $(P<0.05$, Figure 2). The accumulated means from these four samplings were Kopu 4200 and Pitau $2600 \mathrm{~kg}$ DM/ha.

As at Taupo, this site suffered a severe drought from late spring to early summer 1987 , (November-mid January $53 \mathrm{~mm}$ cf $212 \mathrm{~mm}$ mean) followed by a wet autumn (mid January-April $341 \mathrm{~mm}$ of $257 \mathrm{~mm}$ mean). Recovery of white clover following the drought was rapid, with Kopu contributing $45 \%$ and Pitau 30\% DM to the total yield by the March sampling (Figure 2). By June and August, the proportional DM yield advantage of Kopu over Pitau was substantial (Figure 2)

Stolon and Leaf Measurements. SDW, LDW and LAI for Kopu were greater than for Pitau at the autumn anb winter samplings (Table 2). These results closely follow the DM yield differences expressd by Kopu for the same periods (Figure 2).

Table 1: Stolon and leaf parameter means for Taupo, site 1

\begin{tabular}{llccccc}
\hline $\begin{array}{l}\text { Sample } \\
\text { Date' }\end{array}$ & Cultivar & $\begin{array}{c}\text { GP } \\
\text { No./m }\end{array}$ & $\begin{array}{c}\text { SDW } \\
\mathrm{kg} / \mathrm{ha}\end{array}$ & $\begin{array}{c}\mathrm{SL} \\
\mathrm{km} / \mathrm{ha}\end{array}$ & $\begin{array}{c}\text { LDW } \\
\mathrm{kg} / \mathrm{ha}\end{array}$ & LAl \\
\hline Jan a7 & Kopu & 2089 & $\mathrm{a} 25$ & 547 & 634 & $\mathrm{NA}^{\prime}$ \\
& Huia & 2056 & 679 & 659 & 481 & $\mathrm{NA}$ \\
May a7 & Kopu & 4063 & $868^{* *}$ & 793 & 1008 & 4.2 \\
& Huia & 4095 & 498 & 646 & 539 & 2.3 \\
Jul a7 & Koou & 3354 & 741 & 774 & 644 & 1.5 \\
& Huia & 4131 & 487 & 611 & 473 & 1.0 \\
\hline
\end{tabular}

1 Not available

, $(\mathrm{P}<0.05)$

$"(P<0.01)$

Table 2: Stolon and leaf parameter means for Manawatu, site 2.

\begin{tabular}{llcrrrc}
\hline $\begin{array}{l}\text { Sample } \\
\text { Date }\end{array}$ & Cultivar & $\begin{array}{c}\text { GP } \\
\text { No./m² }\end{array}$ & $\begin{array}{c}\text { SDW } \\
\mathrm{kg} / \mathrm{ha}\end{array}$ & $\begin{array}{c}\mathrm{SL} \\
\mathrm{km} / \mathrm{ha}\end{array}$ & $\begin{array}{l}\text { LDW } \\
\mathrm{kg} / \mathrm{ha}\end{array}$ & LAl \\
\hline Feb a7 & Kopu & 4457 & 1137 & 1205 & 1201 & 3.3 \\
& Pitau & 5296 & 928 & 994 & 782 & 1.9 \\
Apr & Kopu & 3207 & 1905 & 1466 & 1993 & 7.7 \\
& Pitau & 3438 & 937 & 901 & $1066^{\prime \prime}$ & $4.2^{\prime \prime}$ \\
Juł a7 & Kopu & 2373 & $1639^{\prime \prime}$ & 903 & a77 & $1.9^{\prime \prime}$ \\
& Pitau & 1721 & $\mathbf{5 1 6}$ & 126 & $\mathbf{3 1 0 *}$ & 0.5 \\
\hline
\end{tabular}

$(P<0.05)$

* $(P<0.01)$

w' $(\mathrm{P}<0.001)$

\section{DISCUSSION}

The ability of Kopu to persist was well demonstrated by its performance at Taupo. This site is typical of the region's extensive pumice derived soils, which are characterised by low water-holding capacity, high phosphate retention and large populations of grass grub. These 
features, combined with the region's extremely variable climate, have all placed considerable stress on clover and grass species alike.

At site 1, Kopu gave a significantly greater white clover DM contribution to the total yield $\mathbf{2 8 \%}$ ), than did Huia (19\%). This contribution was particularly evident in the two cool seasons, autumn and winter.

During dry periods of the year, mineralisation of soil organic matter (OM) results in an accumulation of available $\mathrm{N}$ (Hoglund and Brock 1978), with the result that a stimulation in growth can be expected when soil moisture and temperature are no longer limiting. At the Taupo site, autumn 1987, the significant response by ryegrass in DM and Kopu in SDW, compared with the ryegrass (Huia) mixture, was a direct result of this mechanism, for it followed the severe drought of November to January 1987, and was initiated by wet and mild autumn weather.

At the Manawatu site, Kopu had both seasonal and annual DM production advantages over Pitau. These results showed that the erect habit and larger leaves of Kopu compared with Pitau enabled Kopu to compete more successfully with the vigorous tall growth habit of Matua. Thus Kopu was able to maintain a better grass to clover ratio, particularly during autumn and spring when Matua is most vigorous.

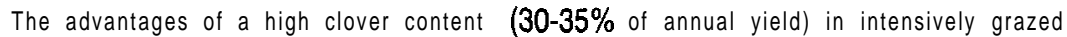
dairy swards are in increased pasture quality and soil fertility. Increased pasture quality increases animal production: cows offered pure white clover (adlib), consumed 33\% more DM and produced $25 \%$ more milk, containing 33\% more fat and $38 \%$ more protein, than cows offered pure ryegrass (Rogers eta/. 1982). Thompson (1978) found similar increases in both sheep and cattle production in clover grazing trials. Nitrogen $(\mathrm{N})$ loss from intensively grazed North Island dairy swards is extremely high, upwards of $350 \mathrm{~kg} \mathrm{~N} / \mathrm{ha}$ pa (Field and Ball 1981). For optimum DM production, these must be replaced either by clover $\mathrm{N}$ fixation, or costly artificial $\mathrm{N}$ inputs. In general $\mathrm{N}$ fixation is directly related to clover growth (Hoglund and Brock 1978). It is therefore, reasonable to assume that Kopu, with its superior DM production demonstrated throughout the year, but particularly in autumn, will contribute a greater proportion of $\mathrm{N}$ to the total $\mathrm{N}$ economy of the system than other white clover cultivars. The result from this increase in soil organic $\mathrm{N}$ may be expected in a grass DM response, as seen at Taupo in autumn 1987.

These factors highlight the importance of a large and vigorous white clover which is able to cope with intensive rotational grazing by dairy cows, and compete with tall aggressive grass species such as Matua. Kopu, with its excellent cool season production, vigorous erect habit and large leaves, and stem nematode resistance, make it well suited to the demands of such a system.

\section{Acknowledgements}

Y Gray, J.C. Van Meer, hl. Grieg, J. Brock, M.J.M. Hay, and T.B. Lyons of Grassland Division DSIR Palmerston North, and to farmers $\mathbf{D}$. Martin of Tirohanga and $\mathbf{D}$. Penny of Linton for their invaluable cooperation.

\section{References}

Field T.R.O.. Ball R. 1961. Nitrogen balance in an intensively utilised dairy farm system. Proceedings NZ Grassland Association 43: 6469

Hoglund J.H., Brock J.L. 1976. Regulation of nitrogen fixation in a grazed pasture. NZ Joumal of Agricultural Research 21: 73-62.

Rogers G.L., Porter R.H.D., Robinson I. 1962. Comparison of perennial ryegrass and white clover for milk production. Abstract; NZ Society of Animal Production 42: 213-214.

Thomson D.J. 1976. Effect of proportion of legumes in the sward on animal output. British Grasslands Society Occasional Symposium 10: 101-109.

Van den Bosch J., Lancashire J.A., Cooper B.M., Lyons T.B., Williams W.M. 1966. G18 white clover a new cultivar for lowland pastures. Proceedings NZ Grassland Association 47: 173-177. 